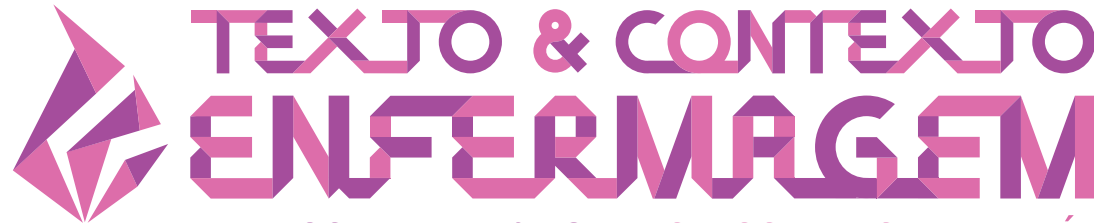

TEXT \& CONTEXT NURSING TEXTO \& CONTEXTO ENFERMERÍA

\section{SPATIAL ANALYSIS OF SUICIDE IN NORTHEASTERN BRAZIL AND ASSOCIATED SOCIAL FACTORS}

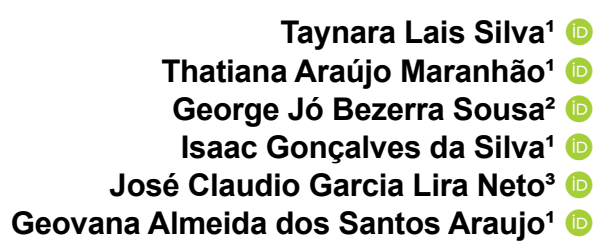

${ }^{1}$ Universidade Estadual do Piauí, Curso de Enfermagem. Parnaíba, Piauí, Brasil. 2Universidade Estadual do Ceará, Programa de Pós-Graduação em Cuidados Clínicos em Enfermagem e Saúde. Fortaleza, Ceará, Brasil.

${ }^{3}$ Universidade de Ribeirão Preto, Curso de Medicina. Guarujá, São Paulo, Brasil.

\begin{abstract}
Objective: to analyze the spatial pattern of mortality due to suicide and social factors associated with its occurrence.

Method: an ecological study that used data from the Mortality Information System (Sistema de Informação sobre Mortalidade, SIM) from 2008 to 2018. The unadjusted and Bayesian mean mortality rates were calculated for each northeastern municipality and the Ordinary Least Squares (OLS) and Geographically Weighted Regression (GWR) non-spatial and spatial regression models were used.

Results: the highest mortality rates due to suicide are especially concentrated in the municipalities of Piaui and Ceará. The predictive variables of suicide were as follows: Gini Index $(p<0.001)$, unemployment rate $\geq 18$ years old $(p<0.001)$, Municipal Human Development Index $(p<0.001)$, illiteracy rate $\geq 18$ years old $(p<0.001)$, per capita income $(p<0.001)$, percentage of people in homes with inadequate walls $(p=0.003)$, percentage of people in homes with inadequate water supply and sewage $(p<0.001)$, and percentage of people vulnerable to poverty who commute for more than one hour to work $(p<0.001)$.

Conclusion: eight predictive variables of mortality due to suicide in the Northeast region were identified that act as risk or protective factors, depending on the municipality under study.
\end{abstract}

DESCRIPTORS: Suicide. Mortality. Spatial analysis. Ecological studies. Epidemiology. 


\section{ANÁLISE ESPACIAL DO SUICÍDIO NO NORDESTE DO BRASIL E FATORES SOCIAIS ASSOCIADOS}

\section{RESUMO}

Objetivo: analisar o padrão espacial da mortalidade por suicídio e fatores sociais associados à sua ocorrência. Métodos: estudo ecológico que utilizou dados do Sistema de Informação sobre Mortalidade (SIM) no período de 2008 a 2018. As taxas médias de mortalidade brutas e bayesianas foram calculadas para cada município nordestino e os modelos de regressão não espacial Ordinary Least Squares (OLS) e espacial Geographically Weighted Regression (GWR) foram utilizados.

Resultados: as maiores taxas de mortalidade por suicídio concentram-se, especialmente, em municípios do Piauí e Ceará. As variáveis preditoras do suicídio foram: Índice de Gini $(p<0,001)$, taxa de desocupação $\geq 18$ anos $(p<0,001)$, Índice de Desenvolvimento Humano Municipal $(p<0,001)$, taxa de analfabetismo $\geq 18$ anos $(p<0,001)$, renda per capita $(p<0,001)$, percentual de pessoas em domicílios com paredes inadequadas $(p=0,003)$, percentual de pessoas em domicílios com abastecimento de água e esgotamento sanitário inadequados $(p<0,001)$ e percentual de pessoas vulneráveis à pobreza que gastam mais de uma hora até 0 trabalho $(p<0,001)$.

Conclusão: foram identificadas oito variáveis preditoras da mortalidade por suicídio no Nordeste que agem como fatores de risco ou de proteção, dependendo do município investigado.

DESCRITORES: Suicídio. Mortalidade. Análise espacial. Estudos ecológicos. Epidemiologia.

\section{ANÁLISIS ESPACIAL DEL SUICIDIO EN EL NORDESTE DE BRASIL Y FACTORES SOCIALES ASOCIADOS}

\section{RESUMEN}

Objetivo: analizar el patrón espacial de la mortalidad por suicidio y los factores sociales asociados a su ocurrencia.

Métodos: estudio ecológico que utilizó datos del Sistema de Información de Mortalidad (SIM) de 2008 a 2018. Se calcularon las tasas de mortalidad media bruta y bayesiana para cada municipio del noreste y se utilizaron los modelos de regresión no espacial de mínimos cuadrados ordinarios (OLS) y el modelo de regresión espacial geográficamente ponderado (GWR).

Resultados: las mayores tasas de mortalidad por suicidio se concentran, especialmente, en las ciudades de Piauí y Ceará. Las variables predictoras de suicidio fueron: índice de Gini $(p<0,001)$, tasa de desempleo $\geq 18$ años $(p<0,001)$, Índice de Desarrollo Humano Municipal $(p<0,001)$, tasa de analfabetismo $\geq 18$ años $(p<0,001)$, renta per cápita $(p<0,001)$, porcentaje de personas en hogares con paredes inadecuadas $(p=0,003)$, porcentaje de personas en hogares con suministro de agua y saneamiento inadecuado $(p<0,001)$ y porcentaje de personas vulnerables a la pobreza que demoran más de una hora en llegar al trabajo $(p<0,001)$.

Conclusión: se identificaron ocho variables predictoras de mortalidad por suicidio en el Nordeste que actúan como factores de riesgo o protectores, según el municipio investigado.

DESCRIPTORES: Suicidio. Mortalidad. Análisis espacial. Estudios ecológicos. Epidemiología. 


\section{INTRODUCTION}

Suicide is a complex and universal human phenomenon that represents a serious public health problem worldwide ${ }^{1}$. It is estimated that, annually, more than 800,000 people die due to suicide, and that at least for every adult who consummates self-provoked death, another twenty attempt suicide ${ }^{2}$.

Most of the self-provoked deaths globally occur in low- and middle-income countries ${ }^{3}$, such as Brazil. In this context, the United Nations (UN) has released strategic documents such as the Sustainable Development Goals (SDGs). One of the goals in this document is to reduce by one third premature mortality due to non-communicable diseases and to promote mental health and well-being ${ }^{4}$.

Brazil is among the ten countries with the highest number of suicides worldwide ${ }^{2}$. Among the Brazilian regions with the highest rates, the Northeast and the Midwest stand out ${ }^{5}$. In this scenario, Piaui is the state with the highest suicide rate in the Northeast region, as it presented a $221.7 \%$ increase in deaths from this cause in the last ten years, and the state capital, Teresina, has the second highest mortality rate due to suicide in young individuals among all the Brazilians capitals (14.4 deaths per 100,000 inhabitants) ${ }^{6}$.

It is important to emphasize that there are few regional studies on the theme of suicide, especially in the Northeast region, where there is an increase in the occurrence of this event ${ }^{7}$. Considering the assumption that high suicide rates can be related to the socioeconomic characteristics of the municipalities ${ }^{8-9}$, there is a need to seek explanations for the differences in the rates of the problem in the northeastern territory. Thus, the importance of epidemiological surveillance and of developing research studies aimed at identifying the municipalities with the highest occurrence and the socioeconomic factors associated with the problem is highlighted, in order to favor their understanding and the prevention possibilities ${ }^{9}$.

Therefore, given the high rates of deaths due to suicide in the country, it is necessary that studies of this nature are carried out in order to collaborate with the understanding of the problem and with the achievement of the international goals proposed by the UN ${ }^{4}$. Therefore, in order to understand how suicide is distributed and affects the health of the population in the Northeast region, the use of geoprocessing tools is essential, as it allows mapping the problem, establishing an association between indicators, cluster visualization and the possibility of reinforcing preventive actions ${ }^{10}$. In view of that, this study aims at: analyzing the spatial pattern of mortality due to suicide and social factors associated with its occurrence.

\section{METHOD}

This is an ecological study that used spatial analysis tools in health. This research has the Brazilian Northeast region as geographic area of interest. According to the last demographic census of 2010 , the Northeast region has a population of $53,078,137$ inhabitants, which corresponds to nearly $28 \%$ of the resident population in Brazil. It is the Brazilian region with the largest number of states, namely: Alagoas (AL), Bahia (BA), Ceará (CE), Maranhão (MA), Paraíba (PB), Pernambuco (PE), Piauí (PI), Rio Grande do Norte (RN) and Sergipe (SE), totaling 1,794 municipalities. As for its territorial extension, it has $1,554,257.0 \mathrm{~km}^{2}$, corresponding to $18.2 \%$ of the total area of the country ${ }^{11}$.

The data of this study were obtained from death certificates registered in the Mortality Information System (SIM) of the Information Technology Department of the Unified Health System (DATASUS) of the Ministry of Health. All deaths registered between 2008 and 2018 whose underlying cause was suicide were included. Therefore, only deaths whose codes X60 to X84 were cited according to the $10^{\text {th }}$ International Classification of Diseases (ICD-10) were selected. 
The socioeconomic and demographic data of the population of the northeastern municipalities were obtained from the Atlas of Human Development in Brazil12, the Brazilian Institute of Geography and Statistics (Instituto Brasileiro de Geografia e Estatística, IBGE) and the DATASUS websites. The indicators collected were as follows: Gini Index, illiteracy rate, Municipal Human Development Index (MHDI), unemployment rate $\geq 18$ years old, dependence ratio, aging rate, percentage of people $\geq$ 18 years old with complete elementary education, percentage of poor people, percentage of people aged from fifteen to twenty-four years old who neither study nor work and are vulnerable, percentage of people in homes with inadequate water supply and sewage, percentage of homes with inadequate walls, percentage of people vulnerable to poverty who commute for more than one hour to work, per capita Gross Domestic Product, and per capita income.

To analyze the time evolution of mortality, the unadjusted suicide data recorded in each year were tabulated in a Microsoft Office Excel spreadsheet. The mean mortality rates obtained with the Tabwin software were used to draw a linear regression line that showed the time evolution of deaths.

For the spatial analysis, the mortality rates due to suicide were calculated for each municipality in the Northeast region. The unadjusted mortality rates were calculated using the number of deaths due to suicide in the municipalities in each year as numerator and, as denominator, standardization by the indirect method was used, in which the population of the central year of the study period (2013) was used, multiplied by 100,000 inhabitants. However, in order to reduce the instability of the unadjusted rates, they were later smoothed using the Local Empirical Bayesian method to correct casual random fluctuations. For such purpose, a spatial proximity matrix (or neighboring matrix) was constructed applying the first order contiguity criterion ${ }^{10}$.

Finally, to identify factors related to mortality due to suicide, the socioeconomic indicators selected were entered into an Ordinary Least Squares (OLS) non-spatial regression model using the step forward method with an entry value of 0.1 . Those that remained in the final model were also entered into a Geographically Weighted Regression (GWR) spatial model. This spatial method was used to verify the variables related to the living conditions of the northeastern population that can be associated with mortality in each municipality of the region. GWR is able to analyze phenomena that vary according to the area in which they are studied since, in addition to using values corresponding to the indicators of a given municipality, it also considers the values of the neighboring municipalities, using a spatial proximity matrix by the contiguity criterion ${ }^{13}$.

The result of the GWR regression is presented in this study in the form of two thematic maps for each socioeconomic indicator: one map for the value of the regression coefficient and another map that represents the statistical significance of each municipality, considering $p<0.05$.

The choice of the best model occurred through the evaluation of the Akaike Information Criterion (AIC) and the coefficient of determination $\left(R^{2}\right)$, in which the lower the AIC value and the higher the $\mathrm{R}^{2}$ value, the better the model's fit ${ }^{14}$.

The TerraView v.4.2. ${ }^{\circledR}$ software was used to obtain the neighboring matrix and to calculate the Bayesian statistics. The OLS non-spatial regression was performed using the Stata $12^{\circledR}$ software and the GWR spatial regression using the GWR4.0.9 ${ }^{\circledR}$ software. The maps were created using the QGis $^{\circledR}$ software, v.2.14.17.

It is noteworthy that all the ethical and legal aspects were respected as recommended by Resolutions 466/12 and 510/2016 of the National Health Council. 


\section{RESULTS}

In the Northeast,27,033 deaths due to suicide were reported from 2008 to 2018, with a mean mortality rate in the study period of 4.87 deaths per 100,000 inhabitants. There was a trend towards an increase in mortality over time (from 4.52 deaths per 100,000 inhabitants in 2008 to 5.64 deaths per 100,000 inhabitants in 2018) with the linear regression line $\left(R^{2}\right)$ being able to explain $82.75 \%$ of the model's variability (Figure 1).

The spatial distribution of the unadjusted and Bayesian mortality rates due to suicide for the 2008-2018 period is shown in Figure 2. It can be seen that, even though it is a map showing unadjusted rates, Map A presents an apparent spatial pattern, with the distribution of the highest coefficients, especially in the municipalities of Piauí, Ceará and Rio Grande do Norte. To reduce dispersion, the local empirical Bayesian method was used to smooth the unadjusted mortality rates due to suicide, making them more stable (Map B). Thus, clusters of deaths (in red and wine color) were found which covered a significant portion of the municipalities in the states of Piauí and Ceará, as well as the Southwest region of Rio Grande do Norte and some municipalities in Paraíba, with rates varying from 7.72 to 15.48 deaths per 100,000 inhabitants.

Table 1 presents the adjustment of the OLS and GWR models for the mortality rate due to suicide. The OLS model indicated the following variables as predictors of mortality due to suicide in the Northeast: Gini Index $(\beta=10.22 ; p<0.001)$, unemployment rate $\geq 18$ years old $(\beta=-0.11 ; p<0.001)$, MHDI $(\beta=24.81 ; p<0.001)$, illiteracy rate $\geq 18$ years old $(\beta=0.13 ; p<0.001)$, per capita income $(\beta=-$ $0.01 ; p<0.001)$, percentage of people in homes with inadequate walls $(\beta=-0.02 ; p=0.003)$, percentage of people in homes with inadequate water supply and sewage $(\beta=-0.04 ; p<0.001)$ and percentage of people vulnerable to poverty who commute for more than one hour to work $(\beta=-0.17 ; p<0.001)$.

In the OLS model, the coefficient of determination $\left(R^{2}\right)$ was 0.125105 and the Akaike Information Criterion (AIC) was 9,426.91, while in the GWR model, the $R^{2}$ coefficient was 0.315880 and the AIC value was $9,056.97$. Therefore, GWR proved to be better adjusted, as it has a lower AIC value and higher $\mathrm{R}^{2}$ than those presented by the OLS model.

Subsequently, the spatial regression model (GWR) of the mortality rate due to suicide was adjusted for the variables that were found to be significant in the OLS model. Thus, Figures 3 and 4 show the association of socioeconomic variables on mortality due to suicide in the northeastern municipalities.

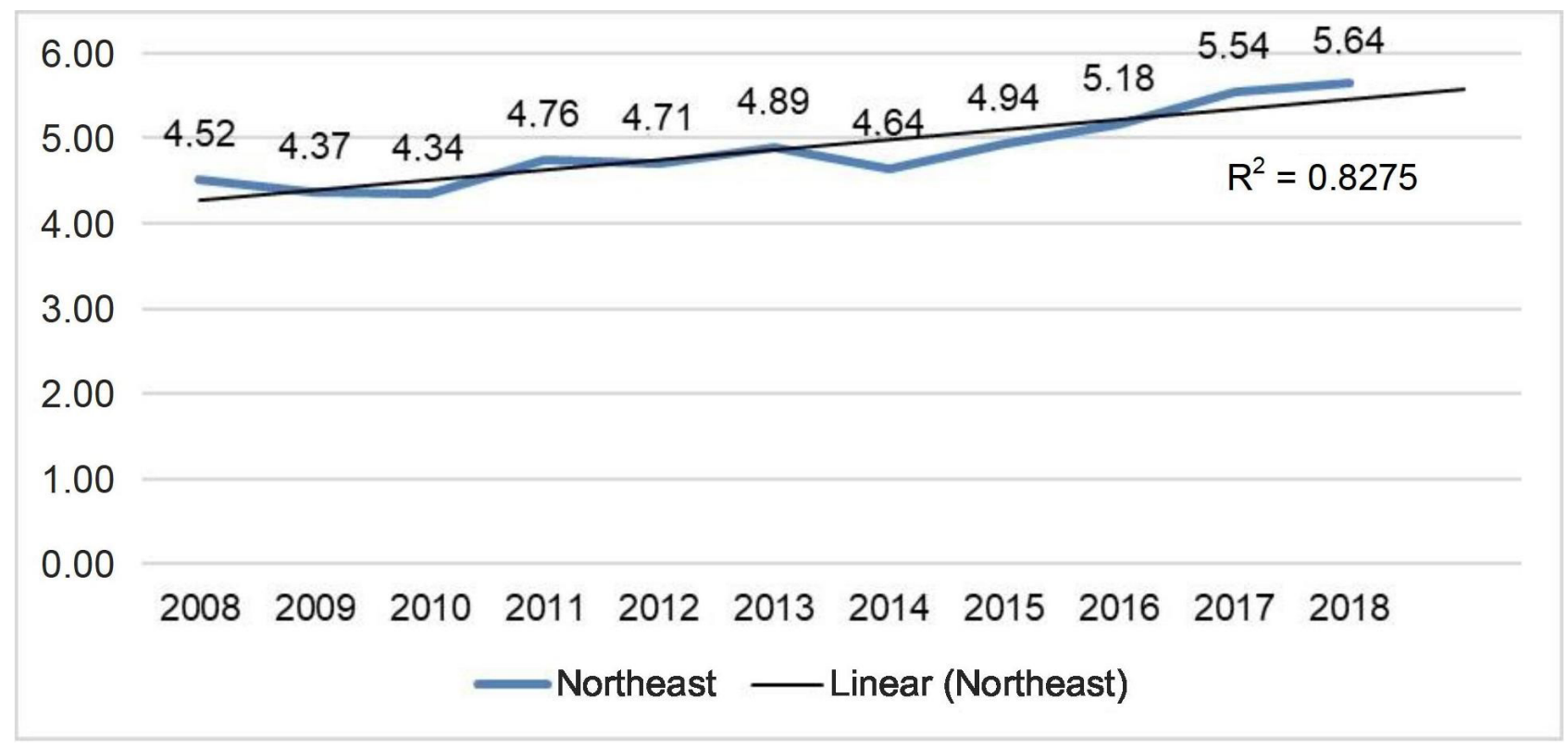

Figure 1 - Time evolution of the mortality rates due to suicide. Northeast region, Brazil, 2008-2018. 


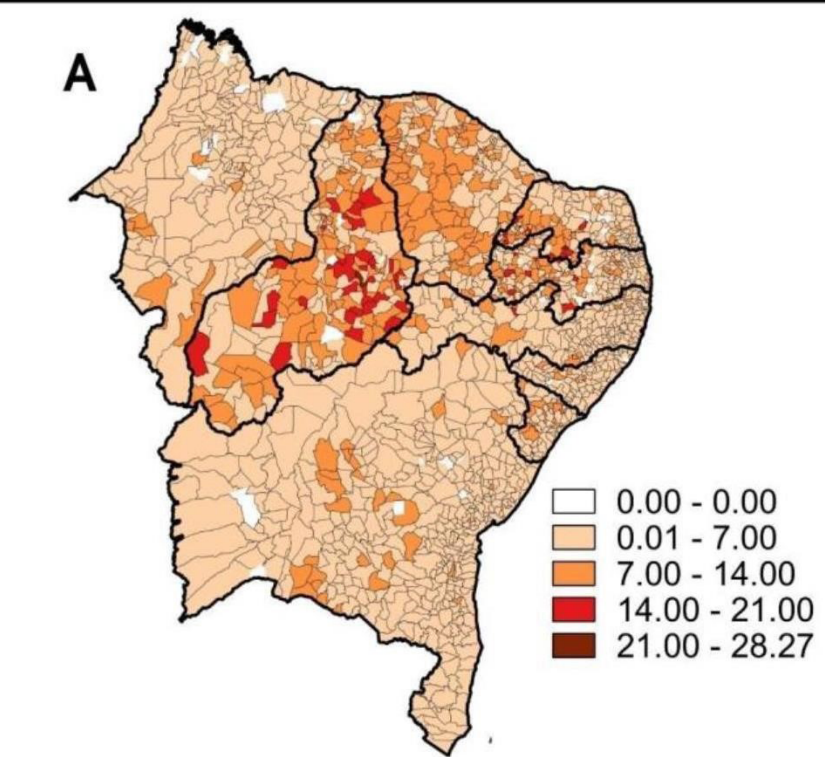

Unadjusted mortality rate due to suicide per 100,000 inhabitants

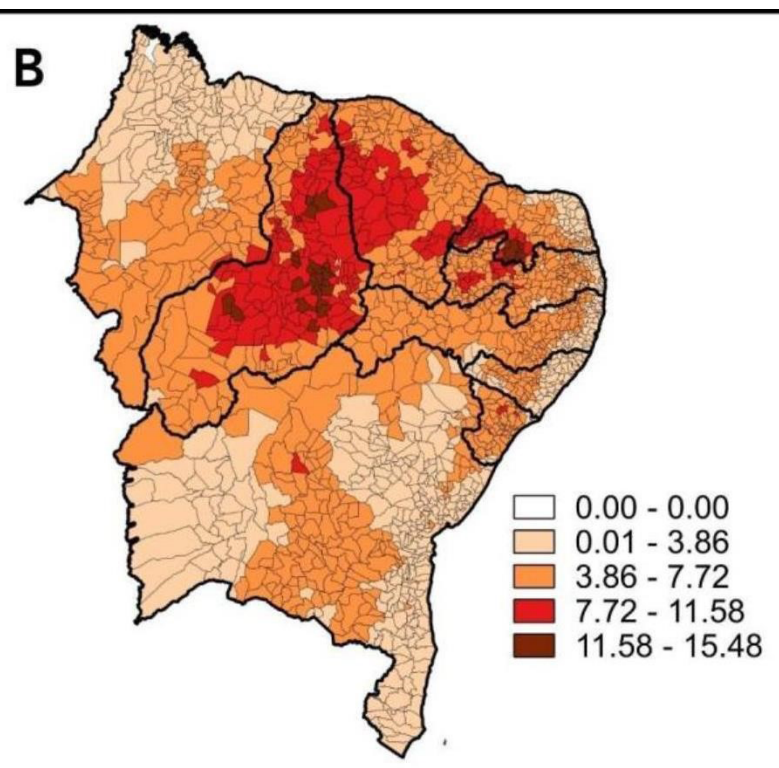

Bayesian mortality rate due to suicide per 100,000 inhabitants

$100 \quad 0 \quad 100 \quad 200 \quad 300 \quad 400 \mathrm{~km}$

Figure 2 - Unadjusted mortality rate due to suicide per 100,000 inhabitants (Map A) and Bayesian mortality rate due to suicide per 100,000 inhabitants (Map B). Northeast region, Brazil, 2008-2018.

Table 1 - Ordinary Least Squares and Geographically Weighted Regression models of the socioeconomic indicators influencing the mortality rate due to suicide. Northeast region, Brazil, 2008-2018.

\begin{tabular}{|c|c|c|c|c|c|}
\hline \multirow{2}{*}{$\begin{array}{l}\text { Socioeconomic } \\
\text { Indicators }\end{array}$} & \multicolumn{2}{|c|}{$\begin{array}{l}\text { Ordinary Least } \\
\text { Squares model }\end{array}$} & \multirow[b]{2}{*}{$\mathbf{p}$} & \multicolumn{2}{|c|}{$\begin{array}{c}\text { Geographically Weighted } \\
\text { Regression model }\end{array}$} \\
\hline & Coefficient & $\begin{array}{l}\text { Standard } \\
\text { error }\end{array}$ & & Coefficient & $\begin{array}{l}\text { Standard } \\
\text { error }\end{array}$ \\
\hline Intercept & - & - & - & -10.283 .930 & 3.001 .412 \\
\hline Gini's Index & 10.22 & 1.89 & $<0.001$ & 10.222 .935 & 1.889 .251 \\
\hline $\begin{array}{l}\text { Unemployment rate } \\
-\geq 18 \text { years old }\end{array}$ & -0.11 & 0.02 & $<0.001$ & -0.114315 & 0.021106 \\
\hline $\begin{array}{l}\text { Municipal Human } \\
\text { Development Index }\end{array}$ & 24.81 & 3.99 & $<0.001$ & 24.813 .882 & 3.992 .622 \\
\hline $\begin{array}{l}\text { Illiteracy rate } \\
\geq 18 \text { years old }\end{array}$ & 0.13 & 0.02 & $<0.001$ & 0.129660 & 0.018127 \\
\hline Per capita income & -0.01 & 0.00 & $<0.001$ & -0.008146 & 0.001536 \\
\hline $\begin{array}{l}\text { People in homes with } \\
\text { inadequate walls (\%) }\end{array}$ & -0.02 & 0.01 & 0.003 & -0.022630 & 0.007693 \\
\hline $\begin{array}{l}\text { People in homes with } \\
\text { inadequate water supply } \\
\text { and sewage }(\%)\end{array}$ & -0.04 & 0.01 & $<0.001$ & -0.039660 & 0.006914 \\
\hline $\begin{array}{l}\text { People vulnerable } \\
\text { to poverty who commute } \\
\text { for more than one hour } \\
\text { to work }(\%)\end{array}$ & -0.17 & 0.05 & $<0.001$ & -0.174276 & 0.052695 \\
\hline
\end{tabular}


It was found that, in municipalities located in eastern Ceará and in some municipalities from Rio Grande do Norte, Pernambuco, Paraíba and northern Bahia, there was a positive and significant association between the Gini Index and mortality due to suicide. This shows that the higher the Gini Index, and therefore inequality, the higher the mortality rate due to suicide in these areas (Figure 3 - Maps A and B).

In municipalities located in the northern region of Piauí, Maranhão and Ceará, in addition to some municipalities from Rio Grande do Norte and Paraíba, it was evidenced that the higher the $\mathrm{MHDI}$, the higher the mortality rate due to suicide. Conversely, in some municipalities in the sertão located on the limit between Ceará and Pernambuco, the higher the MHDI, the lower the mortality rate due to suicide (Figure 3 - Maps $C$ and $D$ ).

A significant negative association was observed between the unemployment rate variable - in people aged $\geq 18$ years old - and the mortality rate due to suicide in a significant portion of the municipalities of Alagoas and Rio Grande do Norte, in addition to municipalities from Piauí, Ceará, Pernambuco and Bahia (Figure 3 - Maps E and F). Maps $\mathrm{G}$ and $\mathrm{H}$ (Figure 3) indicate that the Jaguaribe region, in the state of Ceará, and some municipalities in the central region of Bahia, also presented a significant negative association with the per capita income variable, showing that the lower the per capita income, the higher the mortality rate due to suicide.

Illiteracy rate in people aged $\geq 18$ years old is a risk factor for mortality due to suicide, especially in municipalities from the North of Maranhão and in most of those located in Rio Grande do Norte and Paraíba (Figure 4 - Maps A and B).

It was observed that, in a significant part of northern Maranhão, Piauí and Ceará, there was a significant negative association between the percentage of people in homes with inadequate walls variable and the mortality rate due to suicide. In these territories, the lower the percentage of people in homes with inadequate walls, the higher the mortality rate due to suicide (Figure 4 - Maps $C$ and D).

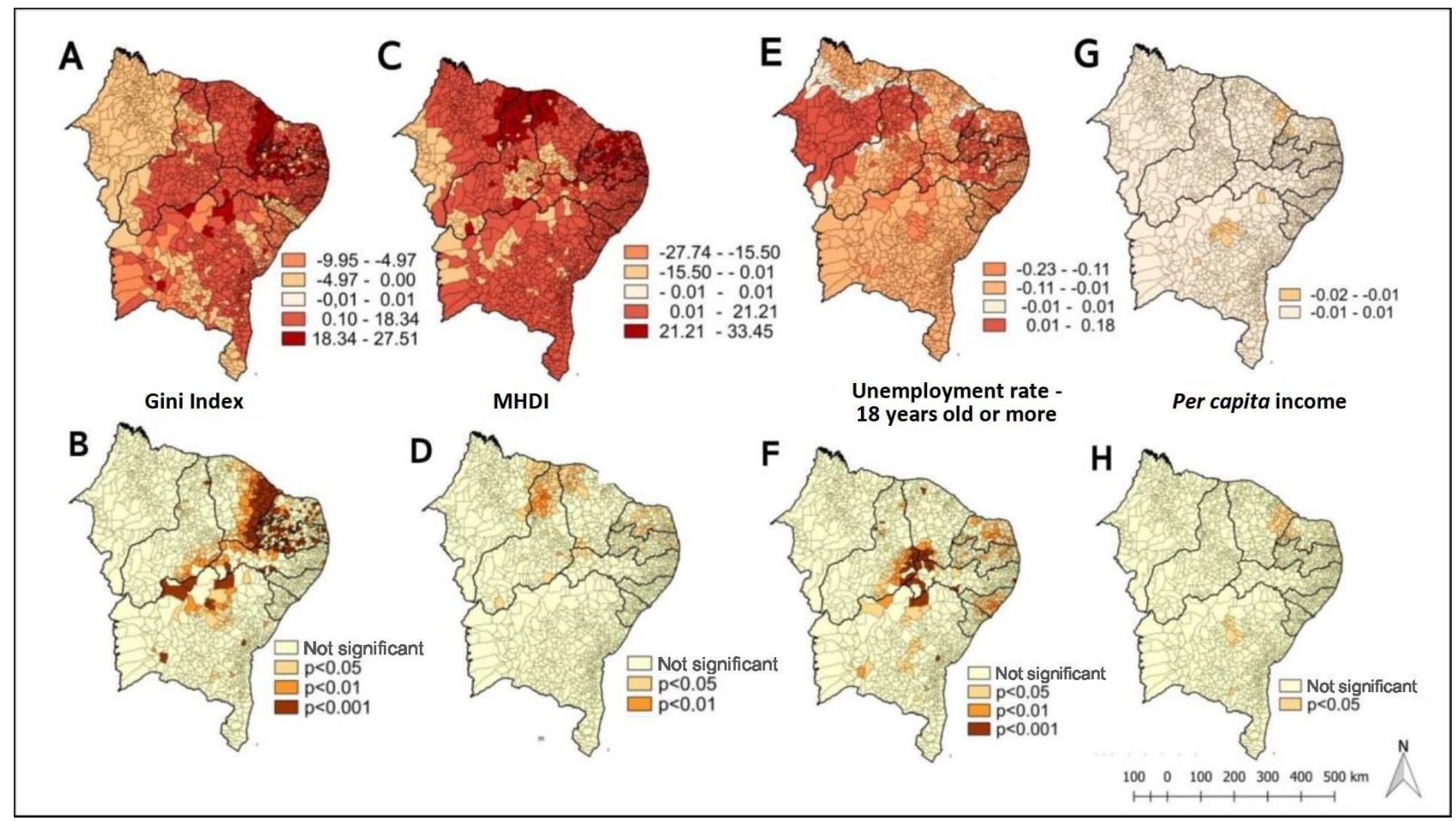

Figure 3 - Spatial distribution of the estimated coefficients and of the statistical significance of the independent variables associated with suicide in the GWR spatial regression model. Northeast region, Brazil, 2008-2018. 


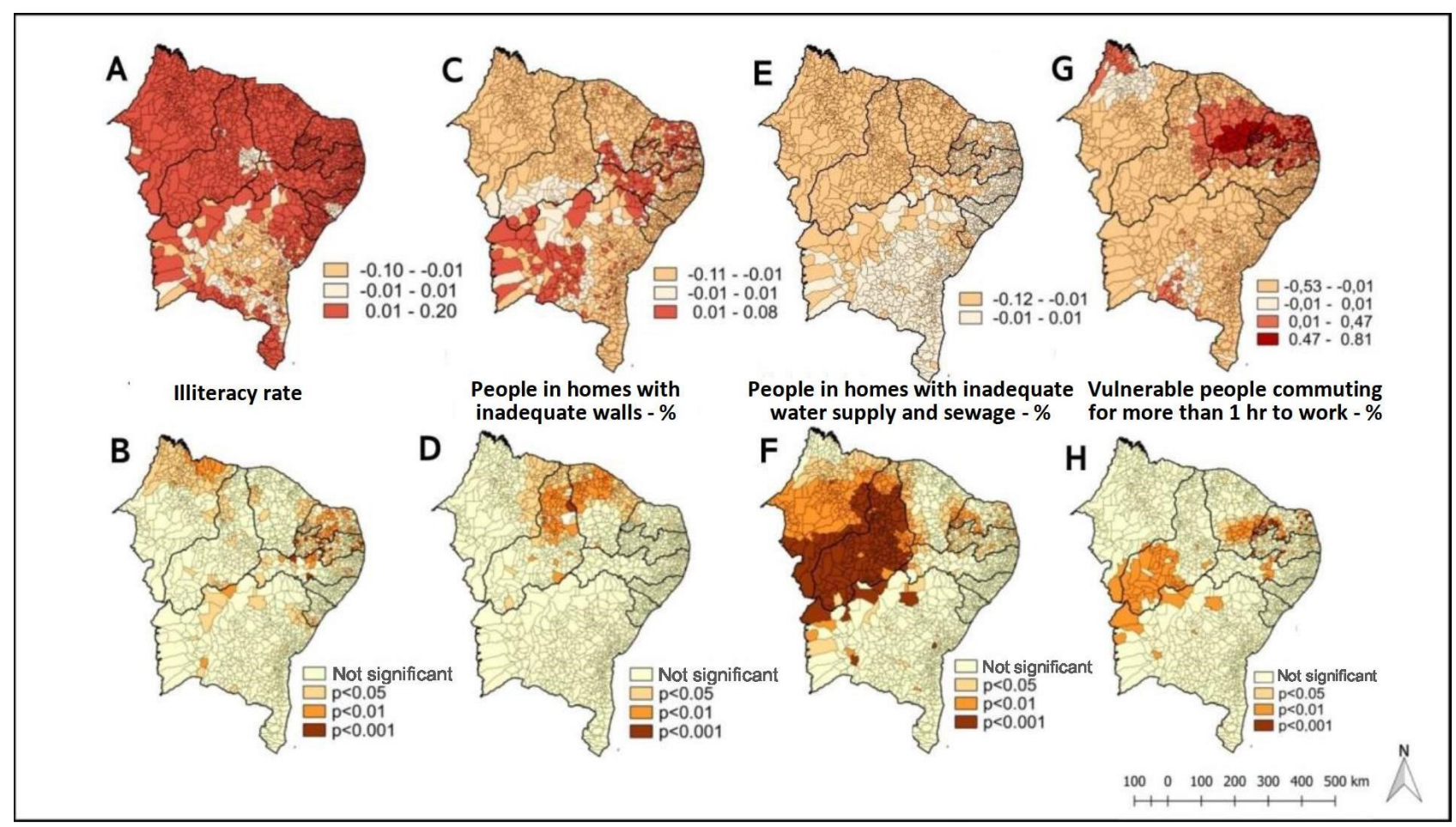

Figure 4 - Spatial distribution of the estimated coefficients and of the statistical significance of the independent variables associated with suicide in the GWR spatial regression model. Northeast region, Brazil, 2008-2018.

The percentage of people in homes with inadequate water supply and sewage was a protection factor in almost the entire state of Piauí and in municipalities in Eastern Maranhão (Figure 4 - Maps E and $F$ ). In turn, maps $G$ and $H$ show that, in southern Piauí, there was a significant negative association, indicating that the lower the percentage of people vulnerable to poverty who commute for more than one hour to work, the higher the mortality rate due to suicide. However, in some municipalities from Ceará, Rio Grande do Norte and Paraíba, the same variable has a positive association with the mortality rate due to suicide, and therefore acts as a risk factor in these territories.

\section{DISCUSSION}

In this study, it was possible to identify the spatial distribution of suicide in the Northeast region and its association with socioeconomic indicators. The maps of the local empirical Bayesian analysis indicate that the states of Piauí and Ceará, as well as some municipalities in Rio Grande do Norte and Paraíba, presented higher mortality due to suicide in the Northeast. In a research study that also assessed the spatial distribution of mortality due to suicide in northeastern Brazil, it was noticed that, among the ten cities with the highest rates, five belonged to Piauí. These municipalities were characterized by terrible socioeconomic conditions, pointed by indicators such as MHDI, illiteracy rate and vulnerability to poverty, among others ${ }^{7}$.

It was found that, in municipalities from Rio Grande do Norte, Paraíba, Bahia and East Ceará, the Gini Index, an important indicator that measures social inequality, proved to be a risk factor for deaths due to suicide. Thus, the greater the inequality in these territories, the greater the rate of selfprovoked deaths. This finding is in consonance with a research study conducted with young individuals which revealed that suicidal acts are more frequent in geographical clusters that are associated with socioeconomic deprivation ${ }^{15}$. Likewise, findings from a systematic review with studies conducted in the European continent point to strong evidence of an increased risk of suicidal behavior in areas that experience high levels of socioeconomic disadvantage ${ }^{9}$. In this context, it is to be noted that the 
history of the Northeast region still presents patterns of persistent socio-spatial inequalities; however, the achievements made by the region in recent years are undeniable, such as reduction of poverty, increase in income, strong growth and transformations in its economic activity ${ }^{16}$.

In turn, the MHDI was positively associated with high mortality rates due to suicide in cities in the North of the states of Piauí, Ceará and Maranhão, in the inland of Rio Grande do Norte and Paraíba, showing that the problem is more serious in more developed cities. An ecological study that evaluated the association between the suicide rates and the HDI in 91 countries found that the rates of self-provoked death increased with increasing HDI levels, since the rates observed were 11.64 and 13.94 deaths per 100,000 inhabitants in extremely and very developed countries, and only 7.93 deaths per 100,000 inhabitants in medium-developed countries. In addition to that, there was also a direct and significant correlation between mortality due to suicide and the percentages of urbanization and Gross Domestic Product of the countries, as well as with women's life expectancy, indicators which, in turn, also show the development level of a territory and the quality of life of its population ${ }^{17}$.

On the other hand, some municipalities in southwestern of Ceará and in the Pernambuco's hinterland presented a negative association with the MHDI, that is, the worse the population's living conditions, the higher the mortality rate due to suicide. In this context, a research study conducted in the United States showed that adolescents living in socioeconomically disadvantaged areas presented a higher risk of suicide attempts. This can be associated with stressors caused by exposure to violence and with the perception of insecurity, as well as with the lack of social support resources ${ }^{18}$.

These opposing results may have occurred due to some confounding factors, such as variables related to religion and race, which are different in different societies. In addition to that, the use of unequal scales to assess socioeconomic status, the type of methodological design of the studies and the size of the population they studied could partially justify this contradiction ${ }^{17}$.

It was found that the higher the illiteracy rate, the higher the mortality rate due to suicide, mainly in municipalities from Rio Grande do Norte, Paraíba and Maranhão. In view of this result, it is to be noted that, although the proportion of illiterate people in the Northeast has been decreasing over time, the region still presents the highest illiteracy rates and the lowest schooling levels in the country, when compared to other Brazilian regions ${ }^{12}$. In particular, the illiteracy rates in Rio Grande do Norte (19.74\%), Paraíba (23.39\%) and Maranhão (22.51\%) are mentioned, which are above the national mean: $10.19 \%{ }^{7,19}$.

Findings similar to those of this paper were found in a study carried out in Iran, which showed that lower literacy rates were associated with higher suicide rates, as well as with lower socioeconomic status, demonstrating the synergy between low socioeconomic and schooling levels and the suicidal act in this territory ${ }^{20}$. A research study that evaluated educational interventions on suicide suggests that actions focused on the school, in which didactic materials that address the risk factors for suicide are distributed, are effective both in gaining knowledge about the problem and in prevention of suicidal ideation and suicide attempts ${ }^{21}$.

In this study, some paradoxical results were also verified, in which social problems described by the indicators constitute protective factors for the mortality rate due to suicide, contrary to the findings of a significant part of the literature on this topic. In a significant part of the municipalities from Alagoas and Rio Grande do Norte, in addition to some municipalities in Piauí, Ceará, Pernambuco and Bahia, the unemployment rate of people aged $\geq 18$ years old presented a negative association with mortality due to suicide, being considered a protective factor. This finding was also observed in an ecological study with data from 91 countries that showed an association between unemployment and lower suicide rates. This can be related to the fact that working populations may have easier access to means for suicide attempts ${ }^{17}$. In addition, the stress triggered by some professions, unbridled competition and the increasing demand for results and attaining ambitious goals in the work environment can compromise mental health and lead to suicidal ideation and behaviors ${ }^{17,22}$. 
The association between mortality due to suicide and work variables suggests that working in precarious situations worsens the quality of life of the working population, causes physical and psychological distress and increases the risk of self-aggression ${ }^{22}$. Work-related emotional distress and overload can reach such severity that the risk of suicide among workers can be greater than that observed among the unemployed ${ }^{23}$. Given the above, it is noteworthy that the relationship between unemployment and suicide is complex and should be interpreted with caution, as it can be influenced by numerous other variables such as age, gender and the moment of the country's economic cycle ${ }^{24}$.

In some municipalities from Piauí, Ceará and Maranhão, the lower the percentage of people in homes with inadequate walls, the higher the mortality rate due to suicide, that is, suicide is associated with better housing conditions in these territories. This result can be related to better socioeconomic conditions in the territories analyzed, in which there may be higher proportions of houses with adequate walls. This can also be due to the housing programs implemented in the country in recent years, which promoted improvements in the quality of housing designed for the population with low purchasing power. However, this policy promoted the displacement of the poorest groups of the population from the most centralized areas and, consequently, their entire structural support, to the peripheries, where the precariousness and/or scarcity of public health and education services stand out. In this way, many housing complexes that were built ended up not guaranteeing social rights to the population assisted. Therefore, it is inferred that the improvement in housing quality did not necessarily translate into improvements in people's quality of life ${ }^{25}$.

In all the municipalities from Piauí and in a significant portion of the municipalities from Maranhão, the increase in the proportion of homes with inadequate water supply and sewage influences the reduction in mortality due to suicide. This result must be interpreted with caution, as it can be justified due to the low population occupation of these states, whose demographic density is only 12.40 inhabitants $/ \mathrm{km}^{2}$ in Piauí and 19.81 inhabitants $/ \mathrm{km}^{2}$ in Maranhão ${ }^{26}$. Therefore, the installation of sewage collection and water supply networks is less suitable due to the low density of buildings, being more convenient to implement individual sanitation solutions such as artesian wells and septic tanks. In view of this, the low coverage of water and sewage networks does not necessarily mean that these places are extremely poor and unhealthy ${ }^{19}$.

A number of municipalities in Ceará and Bahia presented a negative association with the per capita income variable, indicating that, in these locations, the lower the income, the higher the mortality rate due to suicide. On the contrary, research studies conducted both in Brazil ${ }^{15,27}$ and in other countries ${ }^{18,28}$ state that the greater purchasing power of people provides greater availability of essential services such as health, education, culture, employment and housing which, in turn, are protective factors against hopelessness, persistent stress and anxiety, which can lead to suicidal ideation. In this sense, a study conducted in India indicates that more economically developed Indian states presented suicide rates almost four times higher for men and almost three times higher for women when compared to less economically developed states ${ }^{29}$.

The percentage of vulnerable people who commute for more than one hour to work was a protective factor against mortality due to suicide in southern Piauí. This is probably due to the peculiar characteristics of this region, which includes territories from the cerrado of Piauí. These territories stand out for their soybean production and expansion of agricultural employment, leading them to take the first place on the list of exports from Piauí. As a result, they also presented strong dynamism in civil construction, commerce and the service sector, in addition to the increase in the GDP, factors that can be related to improvements in the quality of life of the population in these places and, at the same time, imply a reduction in the complications related to the home-work commute ${ }^{30}$. 
On the other hand, in municipalities from Ceará, the same variable appeared as a risk factor. In this situation, commuting can be exhausting and compromise the individual's quality of life ${ }^{19}$. In addition, excessive commuting time becomes a limiting factor for the individual's social growth, which may compromise the personal search for better living conditions and professional development that directly affect the worker's schooling and income levels. This contributes to not reducing inequalities, especially among the young population, who face the constant lack of social, economic and cultural opportunities from the state or society ${ }^{31}$. It is relevant to clarify that it is necessary to be cautious when interpreting some results presented in this study. Although some predictive variables such as per capita income, percentage of homes with inadequate water supply and sewage and percentage of people in homes with inadequate walls, have presented statistical significance in the OLS and GWR models, their estimated coefficients are very close to zero, showing that the effect of these indicators on the outcome variable is small.

One of the limitations of this study refers to its ecological design, as the analysis of the variables in the population scope does not necessarily represent an association in the individual scope. In addition to that, the use of secondary data can present inconsistencies regarding the amount and quality of the information. However, such limitations did not make the research unfeasible and do not diminish its importance.

\section{CONCLUSION}

It is concluded that there was a trend towards an increase in mortality due to suicide over the period studied. In addition to that, the Bayesian method was able to point out the location of clusters of self-provoked deaths in a significant portion of the municipalities from Piauí and Ceará and in the Southwest of Rio Grande do Norte and Paraíba.

Eight social factors associated with mortality due to suicide in the Northeast region were identified, namely: Gini Index, unemployment rate of people $\geq 18$ years old, MHDI, illiteracy rate of people $\geq 18$ years old, per capita income, percentage of people in homes with inadequate walls, percentage of people in homes with inadequate water supply and sewage, and percentage of people vulnerable to poverty who commute for more than one hour to work. The GWR spatial regression model showed how these factors influence suicide in different territories of Northeastern Brazil and that, depending on the municipality under study, they behave as risk or protective factors.

Given such findings, it is concluded that prevention of mortality due to suicide is not the exclusive responsibility of the health sector, but that it should be considered in the development of public policies for the most diverse sectors of society. In this context, it is worth emphasizing the need for interventions on the social factors associated with suicide in specific municipalities from the Northeast region as an efficient method of preventing mortality due to suicide. Therefore, the strategies to prevent the problem must be directed to the municipalities with the highest occurrence in order to make public health actions more effective.

\section{REFERENCES}

1. Organização Pan-Americana da Saúde (OPAS). Folha informativa-Suicídio [Internet]. 2018 [cited 2020 Aug 05]; Available from: https://www.paho.org/pt/topicos/suicidio

2. Associação Brasileira de Psiquiatria. Suícidio: informando para prevenir. Brasília, DF(BR): Conselho Federal de Medicina; Associação Brasileira de Psiquiatria, Comissão de Estudos e Prevenção de Suicídio; 2014 [cited 2020 Aug 08]. p.1-55. Available from: https://www.hsaude. net.br/wp-content/uploads/2020/09/Cartilha-ABP-Prevenção-Suicídio.pdf 
3. Arensman E, Scott V, De Leo D, Pirkis J. Suicide and suicide prevention from a global perspective. Crisis [Internet]. 2020 Mar [cited 2020 Aug 14];41(1 Suppl):S3-S7. PMID: 32208759. Available from: http://doi.org/10.1027/0227-5910/a000664

4. Programa das Nações Unidas para o Desenvolvimento (PNUD). Plataforma Agenda 2030. Acelerando as transformações para a Agenda 2030 no Brasil. PNUD; IPEA. [Internet]. 2021 [cited 2021 Aug 10]; Available from: http://www.agenda2030.org.br/

5. Carmo ÉA, Ribeiro BS, Nery AA, Casotti CA. Tendência temporal da mortalidade por suicídio no estado da Bahia. Cogitare Enferm [Internet]. 2018 [cited 2020 Aug 08];23(1):e52516. Available from: https://doi.org/10.5380/ce.v23i1.52516

6. Ribeiro JF, Mascarenhas TB, Araújo ACBS, Coelho DMMC, Branca SBP, Coelho DMMC. Sociodemographic profile of suicide mortality. Rev Enferm UFPE OnLine [Internet]. 2018 [cited 2020 Aug 05];12(1):44-50. Available from: https://doi.org/10.5205/1981-8963-v12i01a25087p44-50-2018

7. Santos EGO, Barbosa IR. Conglomerados espaciais da mortalidade por suicídio no nordeste do Brasil e sua relação com indicadores socioeconômicos. Cad Saúde Coletiva [Internet]. 2017 [cited 2020 Aug 05];25(3):371-8. Available from: https://doi.org/10.1590/1414-462x201700030015

8. Santos EGO, Barbosa IR, Severo AKS. Análise espaço-temporal da mortalidade por suicídio no Rio Grande do Norte, Brasil, no período de 2000 a 2015. Cien Saude Coletiva [Internet]. 2020 [cited 2021 Jan 04];25(2):633-43. Available from: https://doi.org/10.1590/1413-81232020252.11042018

9. Cairns JM, Graham E, Bambra C. Area-level socioeconomic disadvantage and suicidal behaviour in Europe: A systematic review. Soc Sci Med [Internet]. 2017 [cited 2020 Aug 08];192:102-11. Available from: https://doi.org/10.1016/j.socscimed.2017.09.034

10. Ministério da Saúde (BR). Abordagens espaciais na saúde pública. Brasília, DF(BR): MS, 2006 [cited 2020 Aug 10]; Available from: https://bvsms.saude.gov.br/bvs/publicacoes/serie_geoproc_ vol_1.pdf

11. Instituto Brasileiro de Geografia e Estatística (IBGE). Censo Demográfico 2010. Características gerais da população, religião e pessoas com deficiência [Internet]. Rio de Janeiro, $R J(B R)$ : IBGE; 2010 [cited 2020 Aug 10]. 215 p. Available from: https://biblioteca.ibge.gov.br/visualizacao/ periodicos/94/cd_2010_religiao_deficiencia.pdf

12. Programa das Nações Unidas para o Desenvolvimento (PNUD). Prêmio Atlas do Desenvolvimento Humano no Brasil: coletânea de Artigos [Internet]. Brasília, DF(BR): Programa das Nações Unidas para o Desenvolvimento; IPEA; FJP; 2015 [cited 2020 Aug 20]. 224 p. Available from: https://www.ipea.gov.br/portal/images/stories/PDFs/livros/livros/livro-pnud-coletanea-artigos.pdf

13. Charlton M, Fotheringham S, Brunsdon C. Geographically Weighted Regression [Internet]. United Kingdon: ESRC National Centre for Research Methods; 2005 [cited 2020 Aug 12]. 31 p. Available from: http://eprints.ncrm.ac.uk/90/1/MethodsReviewPaperNCRM-006.pdf

14. Maranhão TA, Sousa GJB, Alencar CH, Magalhães MAFM, Abreu WC, Pereira MLD. Influence of the social determinants on the incidence of aids in Piauí: an ecological study. Texto Contexto Enferm [Internet]. 2020 [cited 2021 Aug 14];29:e20190235. Available from: https://doi.org/10.1590/1980265X-TCE-2019-0235

15. Alarcão ACJ, Dell' Agnolo CM, Vissoci JR, Carvalho ECA, Staton CA, Andrade L, et al. Suicide mortality among youth in southern Brazil: a spatiotemporal evaluation of socioeconomic vulnerability. Br J Psychiatry [Internet]. 2020 [cited 2021 Jan 04];42(1):46-53. Available from: https://doi.org/10.1590/1516-4446-2018-0352 
16. Hissa-Teixeira K. Uma análise da estrutura espacial dos indicadores socioeconômicos do nordeste brasileiro (2000-2010). Eure [Internet]. 2018 [cited 2020 Aug 22]; 44(131):101-24. Available from: https://doi.org/10.4067/S0250-71612018000100101

17. Khazaei S, Armanmehr V, Nematollahi S, Rezaeian S, Khazaei S. Suicide rate in relation to the Human Development Index and other health related factors: a global ecological study from 91 countries. J Epidemiol Glob Health [Internet]. 2017 [cited 2020 Aug 05];7(2):131-4. Available from: http://dx.doi.org/10.1016/j.jegh.2016.12.002

18. Yildiz M, Demirhan E, Gurbuz S. Contextual socioeconomic disadvantage and adolescent suicide attempts: a multilevel investigation. J Youth Adolesc [Internet]. 2019 Apr [cited 2020 Aug 05];48(4):802-14. Available from: https://doi.org/10.1007/s10964-018-0961-z

19. Instituto Brasileiro de Geografia e Estatística (IBGE). Síntese de Indicadores Sociais: Uma análise das condições de vida da população brasileira 2018 [Internet]. Vol.27, Estudos e Pesquisas. Rio de Janeiro, RJ(BR): IBGE; 2018 [cited 2020 Aug 10]. 151 p. Available from: http://www.ibge. gov.br/home/estatistica/populacao/condicaodevida/indicadoresminimos/sinteseindicsociais2010/ SIS_2010.pdf

20. Haghparast-Bidgoli $H$, Rinaldi $G$, Shahnavazi $H$, Bouraghi $H$, Kiadaliri AA. Socio-demographic and economics factors associated with suicide mortality in Iran, 2001-2010: application of a decomposition model. Int J Equity Health [Internet]. 2018 [cited 2020 Aug 10];17(1):77. Available from: https://doi.org/10.1186/s12939-018-0794-0

21. Pistone I, Beckman U, Eriksson E, Lagerlöf $\mathrm{H}$, Sager $\mathrm{M}$. The effects of educational interventions on suicide: a systematic review and meta-analysis. Int J Soc Psychiatry [Internet]. 2019 [cited 2020 Sep 08];65(5):399-412. Available from: https://doi.org/10.1177/0020764019852655

22. Ceccon RF, Meneghel SN, Tavares JP, Lautert L. Suicídio e trabalho em metrópoles brasileiras: um estudo ecológico. Cien Saude Coletiva [Internet]. 2014 [cited 2020 Aug 08];19(7):2225-34. Available from: https://doi.org/10.1590/1413-81232014197.09722013

23. Pinto LLT, Meira SS, Ribeiro ÍJS, Nery AA, Casotti CA. Tendência de mortalidade por lesões autoprovocadas intencionalmente no Brasil no período de 2004 a 2014. J Bras Psiquiatr [Internet]. 2017 [cited 2020 Sep 10];66(4):203-10. Available from: https://doi.org/10.1590/00472085000000172

24. Iglesias-García C, Sáiz PA, Burón P, Sánchez-Lasheras F, Jiménez-Treviño L, FernándezArtamendi S, et al. Suicide, unemployment, and economic recession in Spain. Rev Psiquiatr Salud Ment [Internet]. 2017 [cited 2020 Sep 10];10(2):70-7. Available from: https://doi.org/10.1016/j. rpsmen.2017.03.001

25. Moura JMO. Programa Minha Casa, Minha Vida na Região Metropolitana de Natal: uma análise espacial dos padrões de segregação e desterritorialização. URBE - Rev Bras Gestão Urbana [Internet]. 2014 [cited 2020 Aug 10];6(583):339. Available from: https://doi.org/10.7213/ urbe.06.003.AC05

26. Instituto Brasileiro de Geografia e Estatística (IBGE). Pesquisa Nacional por Amostra de Domicílios [Internet]. 2018 [cited 2020 Sep 09]; 132 p. Available from: https://agenciadenoticias.ibge.gov. br/media/com_mediaibge/arquivos/81c9b2749a7b8e5b67f9a7361f839a3d.pdf

27. Machado DB, Rasella D, dos Santos DN. Impact of income inequality and other social determinants on suicide rate in Brazil. PLoS One [Internet]. 2015 [cited 2020 Aug 05];10(4):1-12. Available from: https://doi.org/10.1371/journal.pone.0124934

28. Kazemi-Galougahi MH, Mansouri A, Akbarpour S, Bakhtiyari M, Sartipi M, Moradzadeh R. Incomerelated inequality in completed suicide across the provinces of Iran. Epidemiol Health [Internet]. 2018 [cited 2021 Jan 04];40:e2018012. Available from: https://doi.org/10.4178/epih.e2018012 
29. Arya V, Page A, River J, Armstrong G, Mayer P. Trends and socio-economic determinants of suicide in India: 2001-2013. Soc Psychiatry Psychiatr Epidemiol [Internet]. 2018 [cited 2020 Sep 20];53(3):269-78. Available from: https://doi.org/10.1007/s00127-017-1466-x

30. Fundação Centro de Pesquisas Econômicas e Sociais do Piauí (CEPRO). Plano de desenvolvimento sustentável do Piauí (Piauí 2050) [Internet]. 2013 [cited 2020 Aug 10]. 292 p. Available from: http://www.cepro.pi.gov.br/download/201608/CEPRO02_9b568b361f.pdf

31. Ribeiro LCQ, Santos OAS Jr. As metrópoles e a questão social brasileira. Rio de Janeiro, RJ(BR); Revan; 2007. 


\section{NOTES}

\section{ORIGIN OF THE ARTICLE}

Extracted from the research project - Spatio-temporal pattern and social determination of suicide in northeastern Brazil, presented to the Institutional Program for Scientific Initiation Scholarships of Universidade Estadual do Piauí, in 2020.

\section{CONTRIBUTION OF AUTHORITY}

Study desing: Silva TL, Maranhão TA.

Data collection: Silva TL, Silva IG.

Data analysis and interpretation: Silva TL, Maranhão TA.

Discussion of the results: Silva TL, Maranhão TA.

Writing and/or critical review of the content: Silva TL, Maranhão TA, Sousa GJB, Lira Neto JCG.

Review and final approval of the final version: Silva TL, Maranhão TA, Sousa GJB, Silva IG, Lira Neto JCG, Araujo GAS.

\section{ACKNOWLEDGMENT}

We would like to thank the Institutional Program for Scientific Initiation Scholarships of Universidade Estadual do Piauí - PIBIC/UESPI for the scholarship granted to Taynara Lais Silva.

\section{APPROVAL OF ETHICS COMMITTEE IN RESEARCH}

Approved in the Research Ethics Committee of Universidade Estadual do Piauí, Opinion No.3,286,816 and Certificate of Presentation for Ethical Appreciation 07557818.4.0000.5209.

\section{CONFLICT OF INTEREST}

There is no conflict of interest.

\section{EDITORS}

Associated Editors: Elisiane Lorenzini, Ana Izabel Jatobá de Souza.

Editor-in-chief: Roberta Costa.

\section{HISTORICAL}

Received: April 03, 2021.

Approved: August 30, 2021.

\section{CORRESPONDING AUTHOR}

Taynara Lais Silva

taynaralaissilva@gmail.com 